\title{
Rosemary (Rosmarinus officinalis) plants irrigation with secondary treated effluents using Epuvalisation technology
}

\author{
Mohannad Qurie ${ }^{1,2}$, Sabreen Daghra ${ }^{2}$, Mustafa Khamis ${ }^{3}$, Amer Kanan $^{2}$, Zaher Barghouthi ${ }^{4}$, \\ Abdallah Alimari ${ }^{5}$, Sameh Nussiebah ${ }^{1}$ and Rafik Karaman ${ }^{6 *}$ \\ ${ }^{1}$ Faculty of Science and Technology, Al-Quds University Jerusalem, Palestine. \\ ${ }^{2}$ Department of Environment and Earth Sciences, Faculty of Science and Technology, Al-Quds University Jerusalem, \\ Palestine. \\ ${ }^{3}$ Department of Biology, Chemistry and Environmental Sciences, College of Arts and Sciences, American University of \\ Sharjah, Sharjah, United Arab Emirates. \\ ${ }^{4}$ National Agricultural Research Center (NARC), Jenin, Palestine. \\ ${ }^{5}$ International Center for Agricultural Research in Dry Areas (ICARDA), Jenin, Palestine. \\ ${ }^{6}$ College of Pharmacy, Al-Quds University, Jerusalem, Palestine.
}

Accepted 20 May, 2019

\begin{abstract}
The secondary treated effluent (STE) of biological treatment process of Al-Quds University wastewater treatment plant was utilized to irrigate rosemary (Rosmarinus officinalis) using an Epuvalisation system. The Epuvalisation technology is a hydroponic treatment system in which the roots of high value crops are used to polish secondary treated wastewater. This technology is considered to be cheap in construction, easy operation, a long lifespan and needs low maintenance requirements. The plant growth parameters (plant height, fresh and dry weight) demonstrated no significant difference between irrigation with STE and fresh water (FW). Further, the plant analysis of rosemary roots, leaves and stems revealed no influence in irrigation with STE as compared to FW. In addition, no accumulation of sodium or chloride ions in the plant tissues was detected showing no effect of both ions in plants. The water quality of both STE and FW indicated a decrease of biological oxygen demand (BOD) and total dissolved solid (TDS). For STE a reduction of 24 and 39\%, respectively, was found, whereas for FW the reduction was 29 and $31 \%$, respectively. The combined results suggest that the Epuvalisation technology is a promising technique for growth of high value plants using STE with additional value of further water treatment using rosemary plants that has the ability to tolerate salty water. The results show that the growth parameters and the chemical and physical characteristics of the plant in the secondary treated wastewater channels are similar to those grown in fresh water channels. Furthermore, water characteristics are analyzed during the growing season and show significant reduction in COD, BOD, TDS and TSS. Thus, the Epuvalisation system displays a benefit of polishing the secondary treated effluent to a level that could be discharged to the environment safely with the benefit of growing highly beneficial crop.
\end{abstract}

Keywords: Epuvalisation, wastewater, chemical oxygen demand, total dissolved solid, rosemary.

*Corresponding author. E-mail: dr_karaman@yahoo.com.

\section{INTRODUCTION}

Fresh water scarcity is becoming an increasingly acute problem in arid and semi-arid regions. The increase of population growth rate and depletion of water supply sources are the most important pressing factors that 
accelerate the gap between fresh water supply and demand. Treatment and reuse of wastewater is implemented in many countries throughout the world and the treated effluent is used as a reliable source of water, which can fulfill the gap between supply and demand in the water sector (Khan et al., 2008). Wastewater treatment and reuse in agriculture and industrial sectors is one of the alternative solutions for water shortage and scarcity. Both developed and developing countries are implementing different wastewater treatment technologies to provide new water resources, ensure public health, and improve environmental protection, thus avoiding the negative impact of wastewater disposal in the environment (Qurie et al., 2013; Ng et al., 2008). Wastewater treatment technology ranges from traditional low cost treatment as activated sludge to advanced technologies as membrane technologies (Trivedy, 2007). Introduction of a new microalgae strain with a high ability to remove nutrients from palm oil mill effluent POME, can contribute to the effort in finding an efficient and economic technology for improving our environment (Kamyab et al., 2015; Kamyab et al. 2016)

The water consumption in Palestine which is considered as a semi-arid country is divided among three principle sectors: (1) agricultural sector consumes around $70 \%$, and represents the largest consumer of water, (2) domestic sector which consumes about $27 \%$ of the water consumption, and finally (3) industrial sector which consumes only $3 \%$ of the total water consumption (Sbeih, 1996).

The main goal of treating wastewater is to reduce adverse content of suspended solids, oxygen demanding materials, dissolved inorganic compounds and harmful bacteria in the environment (Khalaf et al., 2015). Epuvalisation is a French word that means a biological treatment technique that uses plant, to benefit from plant growth biomass in addition to purifying water (Qurie et al., 2013). The roots of these plants act as a physical filter which holds the suspended matters (Qurie et al., 2013). As a result, the Epuvalisation technology can provide new tertiary purification process of secondary treated wastewater effluent. This technique utilizes the roots of plants as bio-filters for utilizing nitrogen, phosphorus and other macronutrients thus decreasing the total dissolved solids (Qurie et al., 2013). Furthermore, elements and salts from wastewater can be accumulated into the plant tissues. The system mechanism consists of gravitational effluent flowing through open channels to keep the water well aerated. The channels host the plant roots not only for water absorption purposes but for trickling and biological filter functions as well. The technique can be operated in a closed or open cycle system. The open cycle system is less efficient in the removal of nutrients and salinity due to minimal contact time, while the closed cycle system is more efficient because of a relatively longer retention time ( $\mathrm{Ng}$ et al., 2008). In any
Epuvalisation system, the criteria for plants selection are: the ability of the plant to adapt and survive in water as a hydroponic media, the root structure, where hairy roots are more favored due to their high absorption area rendering the plant as more efficient in adsorptions of nutrients and suspended solids, and the salt tolerance of the plant (Xanthoulis et al., 2003). The Epuvalisation technique characterizes cheaper construction and operation with long lifespan, small space and low maintenance requirements with additional advantage of avoiding soil pollution, since no soil used in this technique.

In this research, rosemary plant (Rosmarinous officinalis) was selected to investigate its response towards irrigation with secondary treated effluent (STE) using Epuvalisation technique. Furthermore, this work aimed to investigate the efficiency of rosemary plant in the Epuvalisation system as a tertiary wastewater treatment technique. This is the first attempt in the literature on using rosemary ( $R$. officinalis) for the secondary wastewater polishing using Epuvalisation technique in close lope configuration. The added value of the epuvalization system is the cropping of the highly beneficial rosemary plant which is used as pest control in garden and its leaves are used as food flavoring (Burlando et al., 2010).

\section{MATERIALS AND METHODS}

\section{Wastewater treatment plant}

Al-Quds University wastewater treatment plan twas described previously (Khamis et al., 2012). Briefly, the plant collects a mixture of black (from toilets), gray (from showers and sinks), storm water, and wastewater from a variety of laboratories. The treatment plant consists of a primary treatment (two stage primary settling basin) and secondary treatment (activated sludge). The secondary effluent is then passed through sand filter, chlorinator and alum as coagulating agent before entering the tertiary stage. The tertiary treatment stage consists of two modules of ultra-filtration (UF) units: a hollow fiber (HF) with $100 \mathrm{kD}$ cutoff filters as pre polishing stage followed by spiral wound with $20 \mathrm{kD}$ cutoff UF filters. After the ultrafiltration process, the effluent is filtered by activated carbon column followed by a reverse osmosis (RO).

\section{Epuvalisation system design}

The Epuvalisation system used at Al-Quds University is illustrated in Figure 1. It is composed of two equivalent sections; one is used for irrigation with secondary treated wastewater as hydroponic system while the other is used for irrigation with fresh water as a control. Each system consists of two $0.5 \mathrm{~m}^{3}$ storage tanks (one for influent and the other for effluent) and 4 cropping channels. The influent tank is placed one meter above the Epuvalisation tracks to allow water flow by gravity through the four channels. Each channel (made of galvanized metal) is 3-meter long, $0.45 \mathrm{~m}$ wide and 0.14 $\mathrm{m}$ depth. Small overflow drainage pipes was drilled in the side of each channel to maintain $0.11 \mathrm{~m}$ water level overall the growing season. The 4 channels are placed consecutively with $0.1 \mathrm{~m}$ height 


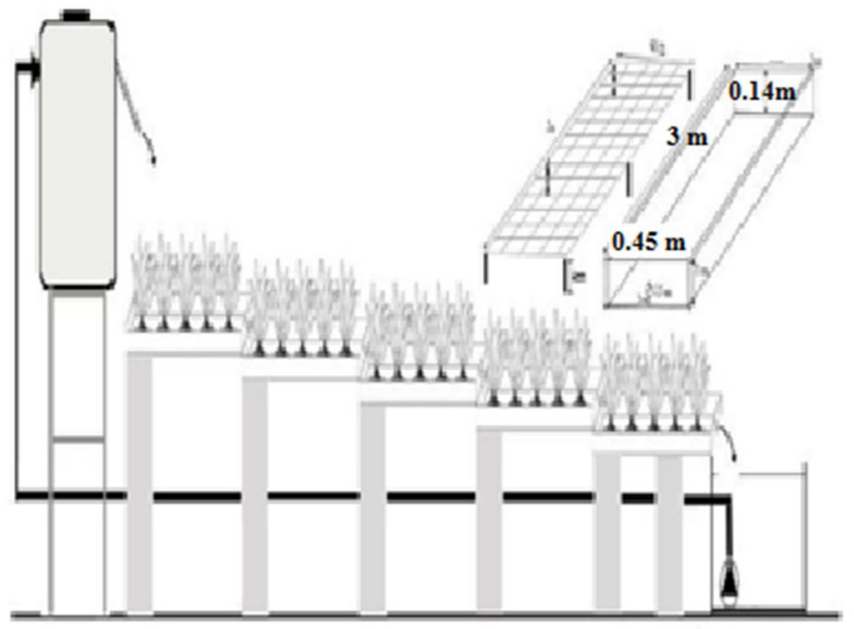

Figure 1. Graphical design for the Epuvalisation system.

difference between each channel. The slope of each channel is about 1 to $1.5 \%$. The effluent storage tank is located under the $4^{\text {th }}$ channel placed in the bottom. The effluent is continuously pumped to the influent tank in close cycle. Air pump was used continuously to maintain optimum oxygen level in channels to enhance the dissolution of oxygen using thin aeration plastic pipes.

\section{Experimental process}

Adaptation stage with fresh water FW and fertilizers was the first stage of our experiment. Aeration stage was conjugated with the process every day for 6 hours and was controlled by a timer. Plants were planted at $0.25 \mathrm{~m}$ distance from each other to permit roots to develop in a sufficient volume. The second stage was irrigation with STE for one system whereas the other system was irrigated with FW as a control. The same quantities of fertilizers were added for both systems. Three closed cycle with 10 days duration each, were used to monitor the plant growth parameters and the water quality. The water quality of the influent and effluent was frequently tested at the initial and final stages of the closed cycle to evaluate the treatment process. Online analysis of EC and TDS was performed on a daily bases to control the efficiency of the treatment system. Standard analytical methods for testing the quality of the water and wastewater were utilized (Eaton, 2005).

\section{Plantation and plant growth parameters}

Young rosemary plants (Rosmarinus officinalis) were grown in channels of both STE and FW augmented with additional nutrients that contain nitrogen, potassium, calcium, phosphorus, magnesium, and iron. Nutrients added in the influent tanks of STE and FW using $5.0,4.0,1.0,0.8,0.7$ and $0.5 \mathrm{mM}$ of total nitrogen, total potassium, calcium, phosphorus, magnesium, and iron, respectively, using the following chemicals: $\mathrm{K}_{2} \mathrm{SO}_{4}, \mathrm{KCl}, \mathrm{KNO}_{3}, \mathrm{Ca}\left(\mathrm{NO}_{3}\right)_{2} \cdot 4 \mathrm{H}_{2} \mathrm{O}, \mathrm{NH}_{4} \mathrm{NO}_{3}$, $\mathrm{KH}_{2} \mathrm{PO}_{4}, \mathrm{MgSO}_{4} \cdot 7 \mathrm{H}_{2} \mathrm{O}, \mathrm{Fe}-\mathrm{Na}$ EDTA. Micronutrients were added in adequate amounts $(\mu \mathrm{M}): 2.97 \quad \mathrm{MnCl}_{2} \cdot 4 \mathrm{H}_{2} \mathrm{O}, 1.24 \quad \mathrm{ZnCl}_{2}, 0.66$ $\mathrm{CuCl}_{2} \cdot 2 \mathrm{H}_{2} \mathrm{O}, 24.75 \mathrm{H}_{3} \mathrm{BO}_{3}, 0.083\left(\mathrm{NH}_{4}\right)_{6} \mathrm{Mo}_{7} \mathrm{O}_{24} \cdot 4 \mathrm{H}_{2} \mathrm{O}$, and 0.0413 $\mathrm{NiCl}_{2}$ ( $\mathrm{Ng}$ et al., 2008; Khalid, 2006). The plants heights were monitored weekly. The dry biomass and fresh biomass were measured at the end of the season. The branching number was measured at the beginning and end of the experiment. At the end of the growing season, the plants were harvested and separated into roots, stems and leaves. Each part was weighed after drying in an open air at room temperature.

\section{Plants tissue analysis}

Dried rosemary (roots, leaves and stems) were analyzed for chemical plant tissue analysis. The chemical analysis included total nitrogen, total phosphorus, sodium, chloride and potassium. Standard methods for soil and plant analysis were used. The plant samples dried at room temperature until constant weight. The plant samples were grinded using electrical blender before digested using complete acid digestion with sulfuric acid and hydrogen peroxide for total nitrogen, total phosphorus, potassium, sodium and chloride analysis (Ryan et al., 1996). Potassium and sodium were analyzed using flame photometer. The total phosphorus was analyzed using the ascorbic acid method at $\Lambda=880 \mathrm{~nm}$ (Murphy and Riley, 1977). Total nitrogen was analyzed using spectrophotometry method at $\Lambda=640 \mathrm{~nm}$ (Ryan et al., 1996).

\section{Instrumentations}

pH-EC-TDS meter (Hanna 18752), Spectrophotometer (Hack, 2010), UV-Visible Spectrophotometer (Shimadzu 1601), Atomic Absorption Flame Emission Spectrophotometer (Shimadzu AA 6200), Flame Photometer (Jenway Heraeussepatech), Oximeter (WTW, Germany), Centrifuge (Labofuge 200), Oven, (D-63450 Kendro) and electronic balance (Shimadzu), Furnace (multi-stages electrotherm, MS 8, BIAF Therm, Israel) were used throughout the work.

\section{Statistics and yield component analysis}

Results were expressed as means and standard deviations for three replicates. All statistical analyses were carried out using Statistical Analysis System (SAS) (SAS Institute Inc., Cary, NC, USA, Release 8.02, 2001). Comparison among data was carried out using the GLM procedure. The Bonferroni procedure was employed with multiple-tests in order to maintain an experiment wise of $5 \%$ (Dunn, 1958).

\section{RESULTS AND DISCUSSION}

\section{Plant growth parameters}

Plant growth parameters (plant height, fresh weight, and dry weight and average number of branching) were monitored during the season and at harvesting time. Figures 2 to 4 summarize the plants growth parameters of rosemary plants irrigated with both STE and FW.

The rosemary plants height results indicate an increase in plant height during the time with no significant difference between the irrigation by both sources, STE and FW. The same trend was observed for the rosemary fresh and dry weights at the end of the experiment showing no significant difference. The average number of branching in both media showed an increase in the 


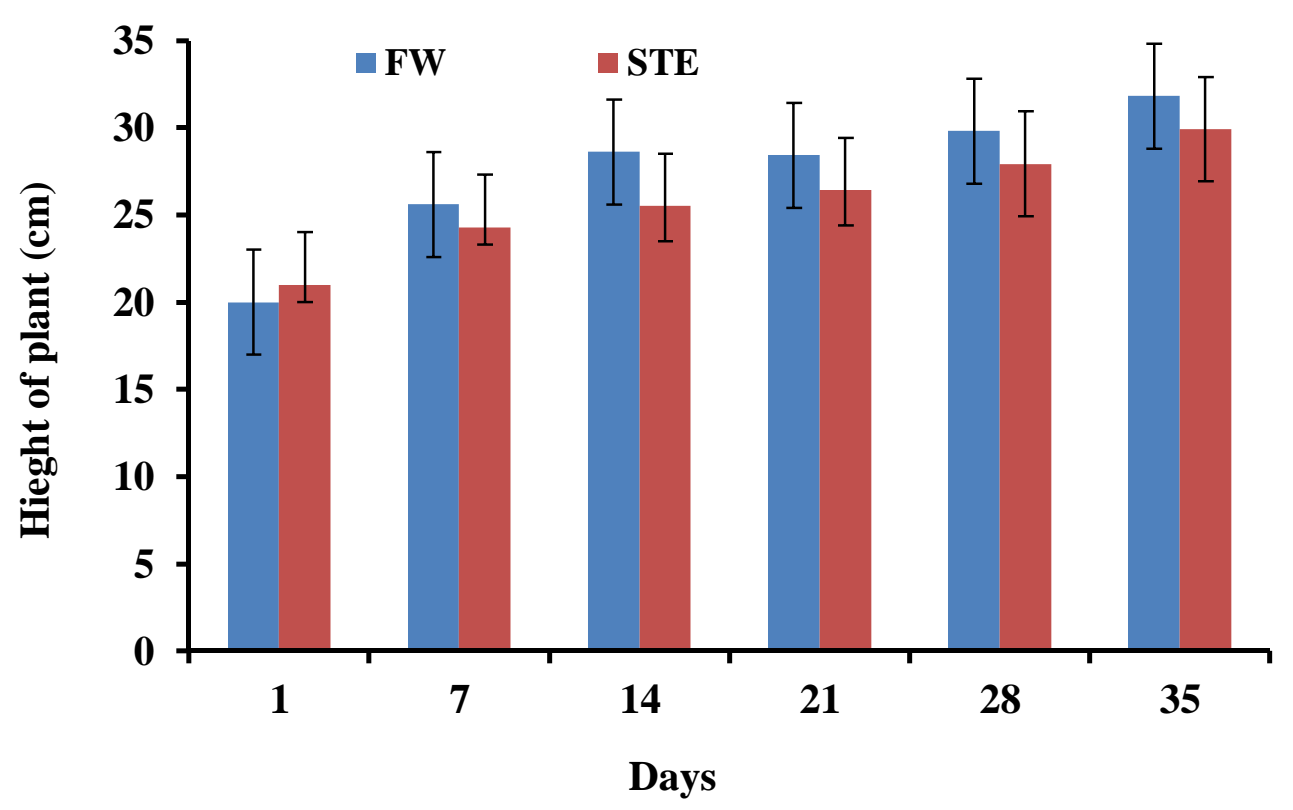

Figure 2. Variation of rosemary height $(\mathrm{cm})$ as a function of time (days) during season of Epuvalisation experiment which irrigated with both types of water (STE and FW).

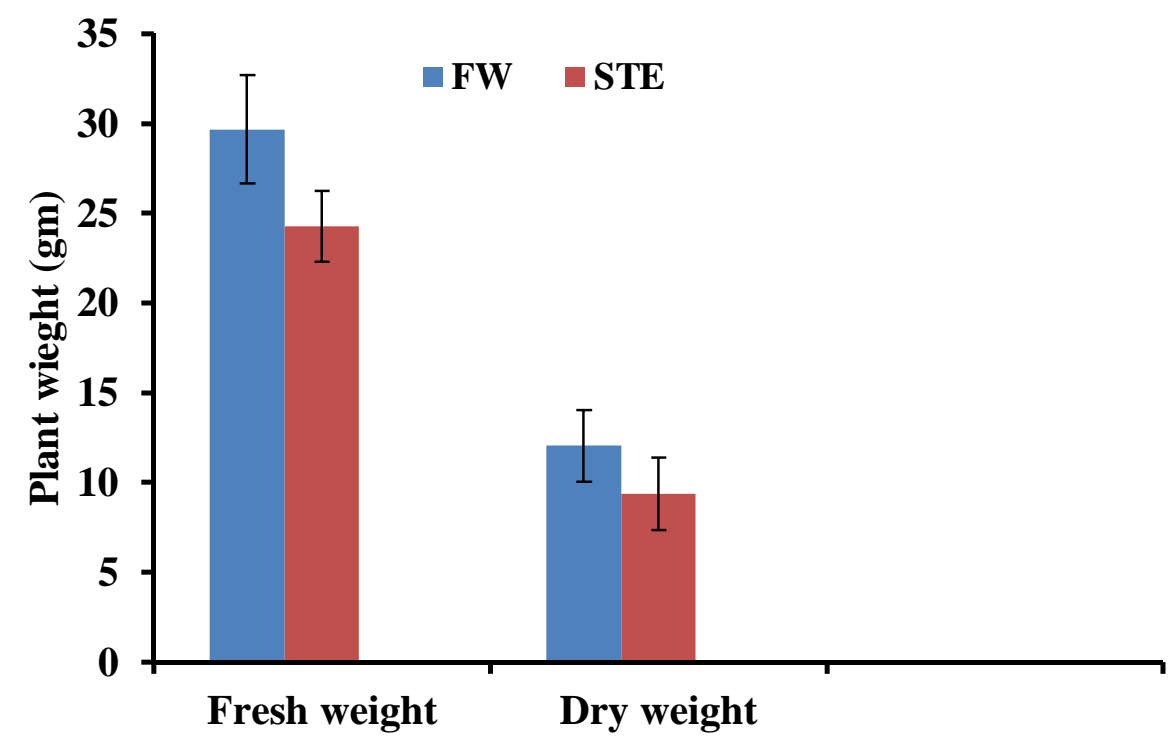

Figure 3. Variation of rosemary weight in $(\mathrm{g})$ for both fresh and dry plants irrigated with STE and FW.

number of branching in all rosemary plants. This observation indicates that rosemary plants were growing horizontally. However, no significant difference between both irrigations was observed. Similar studies on irrigation of rosemary (Rosmarinus officinalis) with treated wastewater showed that the plants were adapted to wastewater irrigation with increasing plant height (Rayan et al., 2015; Bozdogan, 2015).

\section{Chemical composition of plant tissues}

Rosemary plants were harvested after the growing season, dried, separated into roots, stems and leaves. Finally were digested for chemical analysis of the various nutrient contents as shown in Figures 5, 6 and 7.

Rosemary plants grown with STE have accumulated higher total nitrogen in their roots compared to plants 


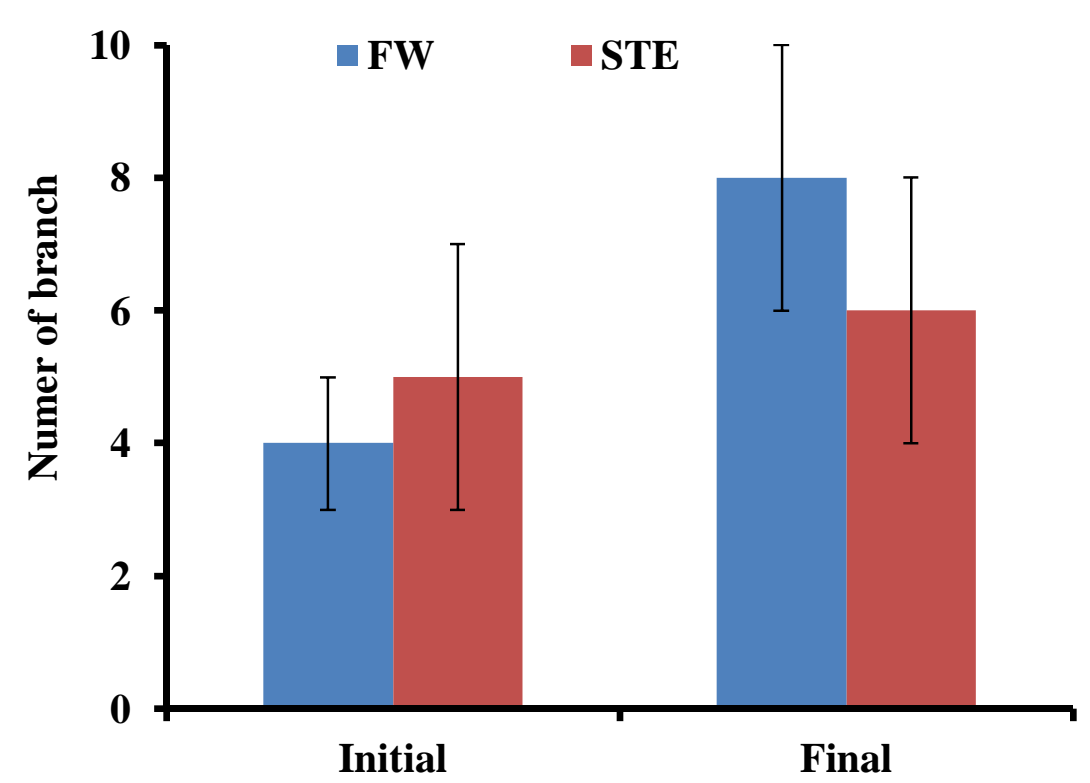

Figure 4. Variation of average rosemary branching number of plants irrigated with STE and FW at the beginning of the experiment and after 6 weeks.

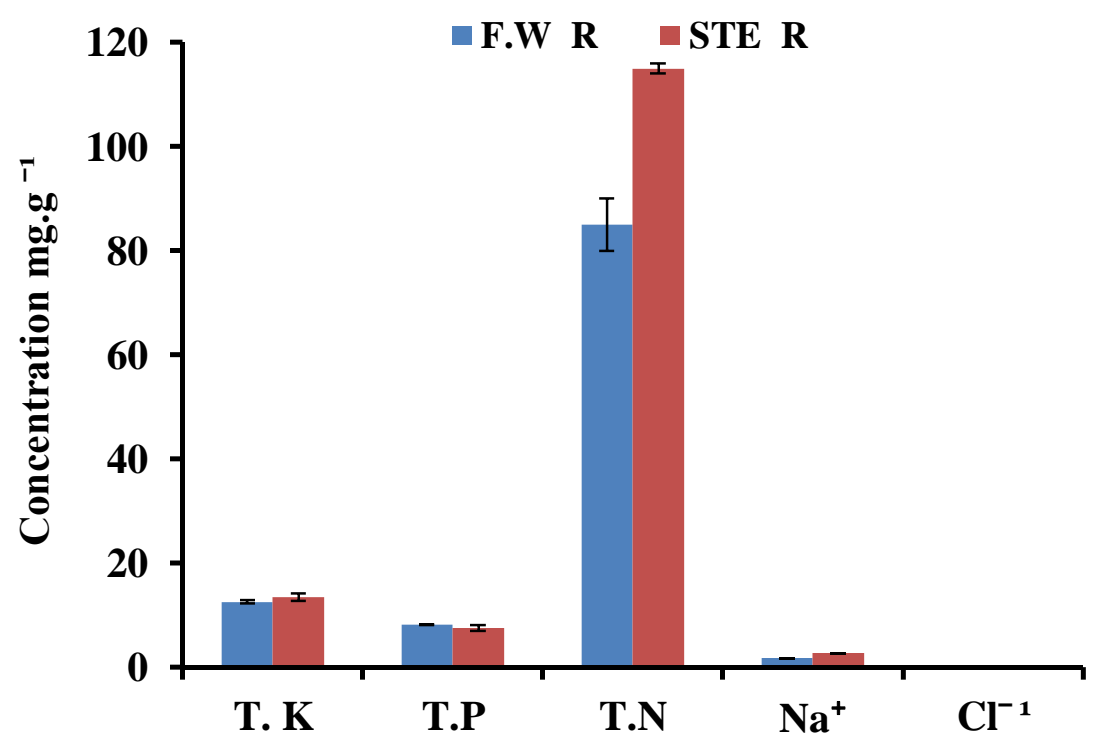

Figure 5. Total nutrients content of rosemary roots after 6 weeks of Epuvalisation irrigated with STEas compared with FW. Mean values \pm standard deviations (SD) of three replicates are reported.

irrigated with FW (Figure 5). Both STE and FW treated plants have accumulated the same amount of total potassium and phosphorous, with low amount of $\mathrm{Na}^{+}$and $\mathrm{Cl}^{-}$showing no salinity effect of STE on the plant's roots. Figure 6 shows higher accumulation of total potassium with STE in the stems compared to plants irrigated with FW. On the other hand, the concentrations of TN and TP in rosemary stems grown showed no significant difference between both water irrigations, STE and FW.

Nitrogen was accumulated in higher amounts compared to the other macronutrients in all parts of the rosemary plants. Low sodium content ranging between (1.63 and $2.82 \mathrm{mg} / \mathrm{g}$ ) was found almost equal in plants irrigated with STE or FW. No particular accumulation of 


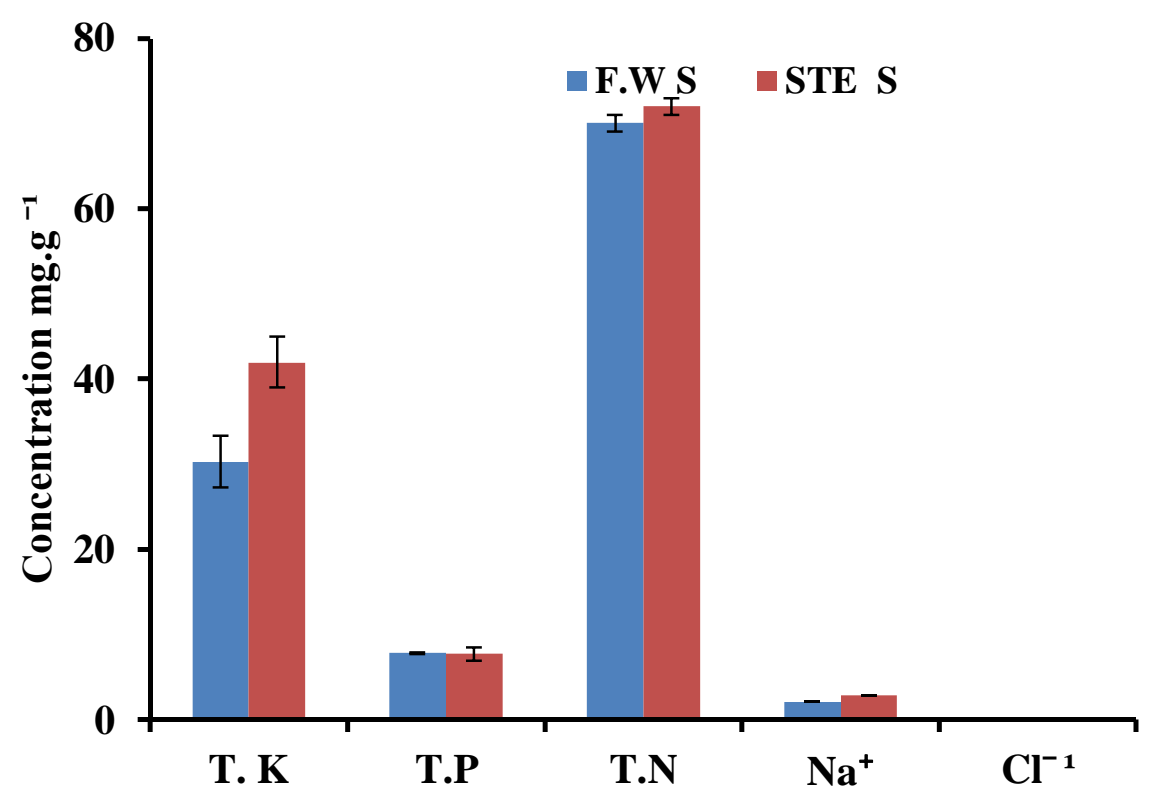

Figure 6. Total nutrients content of rosemary stems after 6 weeks of Epuvalisation irrigated with STE as compared with FW. Mean values \pm standard deviations (SD) of three replicates are reported.

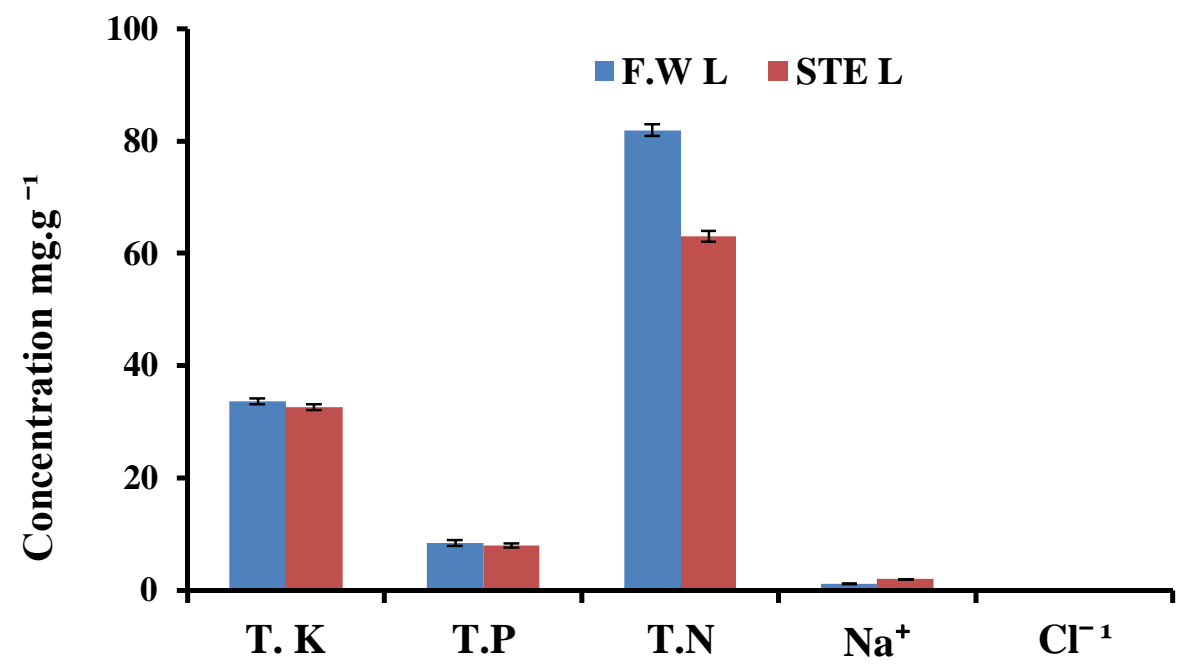

Figure 7. Total nutrients content of rosemary leaves after 6 weeks of Epuvalisation irrigated with STE as compared with FW. Mean values \pm standard deviations (SD) of three replicates are reported.

chloride with concentration range $(0.01$ and $0.07 \mathrm{mg} / \mathrm{g})$ was observed in the roots, stems and leaves of the rosemary plants. According to the study results, rosemary can be considered as a tolerant plant towards salt, ornamental shrubs with maximum permissible EC of 6000 to $8000 \mu \mathrm{S} . \mathrm{cm}^{-1}$ (PWA 2003). Further, the Epuvalisation results agree with previous studies and demonstrate that rosemary ( $R$. officinalis), when grown in soil, is suitable as industrial crops for essential oil and antioxidant production when irrigated with secondarytreated municipal effluents. This is because the rosemary yield and quality were not affected by the type of water used for irrigation (Fayaz and Hossein, 2011).

\section{Water quality}

The effluent of the biological treatment unit in the 
wastewater treatment plant at Al-Quds University (STE) was used for rosemary plants irrigation using Epuvalisation technique. Fresh water from the site was used as a control. The chemical, physical and biological characteristics of STE and FW are presented in Table 1.

Inspection of Table 1 reveals that STE contains high population of fecal coliform, total coliform and total plate count with high turbidity. All those values are higher than the Palestinian standard limitation for agriculture irrigation (Bozdogan, 2015; WHO, 2008).

The electrical conductivity (EC) of STE $(1830 \mu \mathrm{S} / \mathrm{cm})$ is higher than that of $\mathrm{FW}(1060 \mu \mathrm{S} / \mathrm{cm})$ indicating higher salt content in STE. The maximum limits for EC in drinking water per WHO standards is about $1500(\mu \mathrm{S} / \mathrm{cm})$ (PWA 2003). According to Palestinian standards, STE can be considered as medium quality water. This is based on the measured BOD and FC values.

The influent and effluent quality of FW and STE were monitored during the Epuvalisation experiments. Water samples were collected and analyzed for chemical, biological and physical characteristics after each cycle which lasted for 10 days. Table 2 depicts typical water analysis for an average of three cycles.

Table 2 indicates a decrease of $13 \%$ in the chemical oxygen demand (COD) and $39 \%$ in total dissolved solid (TDS) upon irrigation with STE water, whereas, a decrease of 16 and $31 \%$, respectively, were observed in the case of FW.

Potassium concentration for both treatments demonstrates a decrease of 31 and $33 \%$ for FW and STE, respectively. This decrease can be attributed to the uptake of $\mathrm{K}^{+}$by rosemary plants as major nutrients. Similar trends were observed in the other nutrients such as $\mathrm{Ca}^{+2}, \mathrm{Mg}^{+2}$ and $\mathrm{Na}^{+}$.

The combined results revealed that rosemary plants can be used as a polisher of STE with a removal efficiency of $24 \%, 26 \%$ and $13 \%$ for BOD, TDS and COD, respectively. This indicates that the treated effluent of the Epuvalization system have an acceptable water quality and hence it can be used as an alternative source for irrigation for crops in arid and semi-arid regions, thus preserving fresh water resources (FAO, 2007; AlJayyousi, 2013; Vo et al., 2014).

Table 1. Chemical, physical and biological analysis of STE and FW employed for irrigation of rosemary plant using Epuvalisation technology.

\begin{tabular}{lcc}
\hline Test & FW & STE \\
\hline $\mathrm{pH}$ & $7.5 \pm .2$ & $7.7 \pm .3$ \\
$\mathrm{EC}(\mu \mathrm{S} / \mathrm{cm})$ & $1060 \pm 50$ & $1830 \pm 50$ \\
$\mathrm{TDS}\left(\mathrm{mg} \cdot \mathrm{L}^{-1}\right)$ & $510 \pm 50$ & $1100 \pm 50$ \\
$\mathrm{TSS}\left(\mathrm{mg} \cdot \mathrm{L}^{-1}\right)$ & $1 \pm 0.1$ & $76 \pm 3.2$ \\
Turbidity $\left(\mathrm{mg} \cdot \mathrm{L}^{-1}\right)$ & $1 \pm 0.1$ & $52 \pm 2$ \\
$\mathrm{COD}\left(\mathrm{mg} \cdot \mathrm{L}^{-1}\right)$ & $117 \pm 20$ & $192 \pm 55$ \\
$\mathrm{BOD}\left(\mathrm{mg} \cdot \mathrm{L}^{-1}\right)$ & $58 \pm 5$ & $117 \pm 30$ \\
$\mathrm{Mg}^{2+}\left(\mathrm{mg} \cdot \mathrm{L}^{-1}\right)$ & $12 \pm 3$ & $26 \pm 0.5$ \\
$\mathrm{Ca}^{2+}\left(\mathrm{mg} \cdot \mathrm{L}^{-1}\right)$ & $28 \pm 15$ & $60 \pm 0.2$ \\
$\mathrm{~K}^{+}\left(\mathrm{mg} \cdot \mathrm{L}^{-1}\right)$ & $16 \pm 26$ & $38 \pm 5$ \\
$\mathrm{Na}^{+}\left(\mathrm{mg} \cdot \mathrm{L}^{-1}\right)$ & $47 \pm 3$ & $78 \pm 2$ \\
$\mathrm{TN}^{*}\left(\mathrm{mg} \cdot \mathrm{L}^{-1}\right)$ & $6.4 \pm 0.1$ & $29.2 \pm 2.5$ \\
$\mathrm{PO}_{4}^{3-}\left(\mathrm{mg} \cdot \mathrm{L}^{-1}\right)$ & $37 \pm 3$ & $63.70 \pm 2$ \\
$\mathrm{FC}\left(\mathrm{cfu} / \mathrm{ml}^{-1}\right)$ & 0 & $3^{\star} 10^{3}$ \\
$\mathrm{TC}\left(\mathrm{cfu} / \mathrm{ml}^{3}\right)$ & $<1000$ & $5^{\star} 10^{3}$ \\
$\mathrm{TPC}$ & $<1000$ & $20^{\star} 10^{3}$ \\
\hline
\end{tabular}

*as $\mathrm{NH}^{4+}$ and $\mathrm{NO}^{3-}\left(\mathrm{mg} \cdot \mathrm{L}^{-1}\right)$.

Table 2. Physical, chemical and biological quality of STE and FW employed in the Epuvalisation system. The results are average of three cycles with 10 days each. Mean values \pm standard deviations (SD) are reported.

\begin{tabular}{|c|c|c|c|c|c|c|}
\hline \multirow{2}{*}{ Test } & \multicolumn{2}{|c|}{ FW } & \multirow{2}{*}{ Percentage change } & \multicolumn{2}{|c|}{ STE } & \multirow{2}{*}{ Percentage change } \\
\hline & Influent & Effluent & & Influent & Effluent & \\
\hline $\mathrm{pH}$ & $7.1 \pm 0.1$ & $7.2 \pm 0.1$ & - & $7.4 \pm 0.1$ & $8.2 \pm 0.1$ & - \\
\hline $\mathrm{EC}\left(\mu \mathrm{S} . \mathrm{cm}^{-1}\right)$ & $1067 \pm 25$ & $763 \pm 35$ & 29 & $1837 \pm 25$ & $1350 \pm 20$ & 27 \\
\hline TDS (mg.L-1) & $540 \pm 12$ & $407 \pm 15$ & 25 & $1067 \pm 20$ & $670 \pm 15$ & 37 \\
\hline SS (mg.L-1) & $1.7 \pm 0.1$ & $1.2 \pm 0.1$ & 29 & $64 \pm 5$ & $44 \pm 5$ & 31 \\
\hline TUR (NTU) & $0.7 \pm 0.05$ & $0.3 \pm 0.05$ & 57 & $49 \pm 11$ & $32 \pm 2$ & 35 \\
\hline $\mathrm{COD}\left(\mathrm{mg} \cdot \mathrm{L}^{-1}\right)$ & $107 \pm 15$ & $77 \pm 8$ & 27 & $217 \pm 23$ & $162 \pm 15$ & 25 \\
\hline $\mathrm{BOD}\left(\mathrm{mg} \cdot \mathrm{L}^{-1}\right)$ & $46 \pm 3$ & $34 \pm 2$ & 23 & $86 \pm 2$ & $64 \pm 5$ & 23 \\
\hline $\mathrm{Mg}^{2+}\left(\mathrm{mg} \cdot \mathrm{L}^{-1}\right)$ & $2.32 \pm 0.1$ & $1.71 \pm 0.1$ & 26 & $24 \pm 1$ & $18 \pm 1$ & 22 \\
\hline $\mathrm{Ca}^{2+}\left(\mathrm{mg} \cdot \mathrm{L}^{-1}\right)$ & $1.26 \pm 0.2$ & $0.86 \pm 0.05$ & 32 & $58 \pm 0.5$ & $42 \pm 1$ & 26 \\
\hline $\mathrm{K}^{+}\left(\mathrm{mg} \cdot \mathrm{L}^{-1}\right)$ & $4.32 \pm 0.2$ & $1.77 \pm 0.3$ & 59 & $38 \pm 2$ & $31.7 \pm 0.8$ & 14 \\
\hline $\mathrm{Na}^{+}\left(\mathrm{mg} \cdot \mathrm{L}^{-1}\right)$ & $37.9 \pm 0.8$ & $26.8 \pm 0.7$ & 29 & $76 \pm 2$ & $51.8 \pm 0.8$ & 6 \\
\hline
\end{tabular}




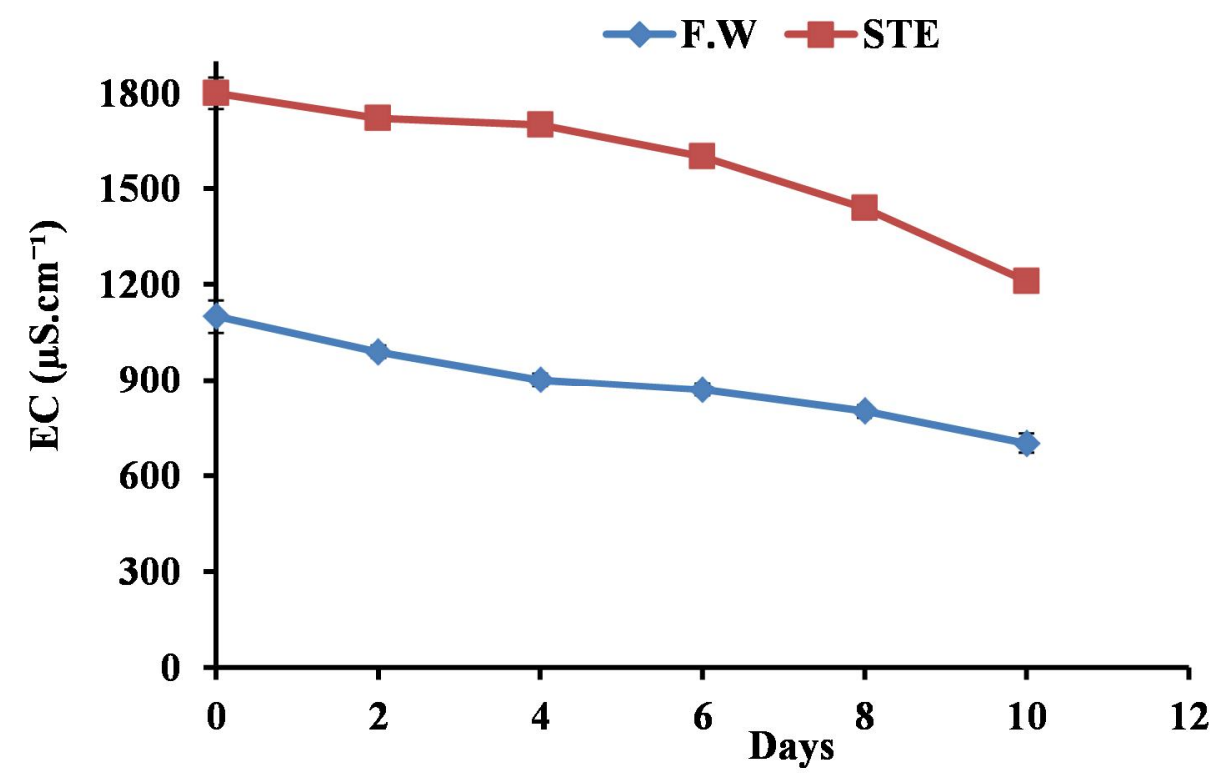

Figure 8. Variation of EC vs. time (days) using STE as compared to FW during the closed cycle (10 days of operation). Both treatments contained the same quantity of macro and micronutrients.

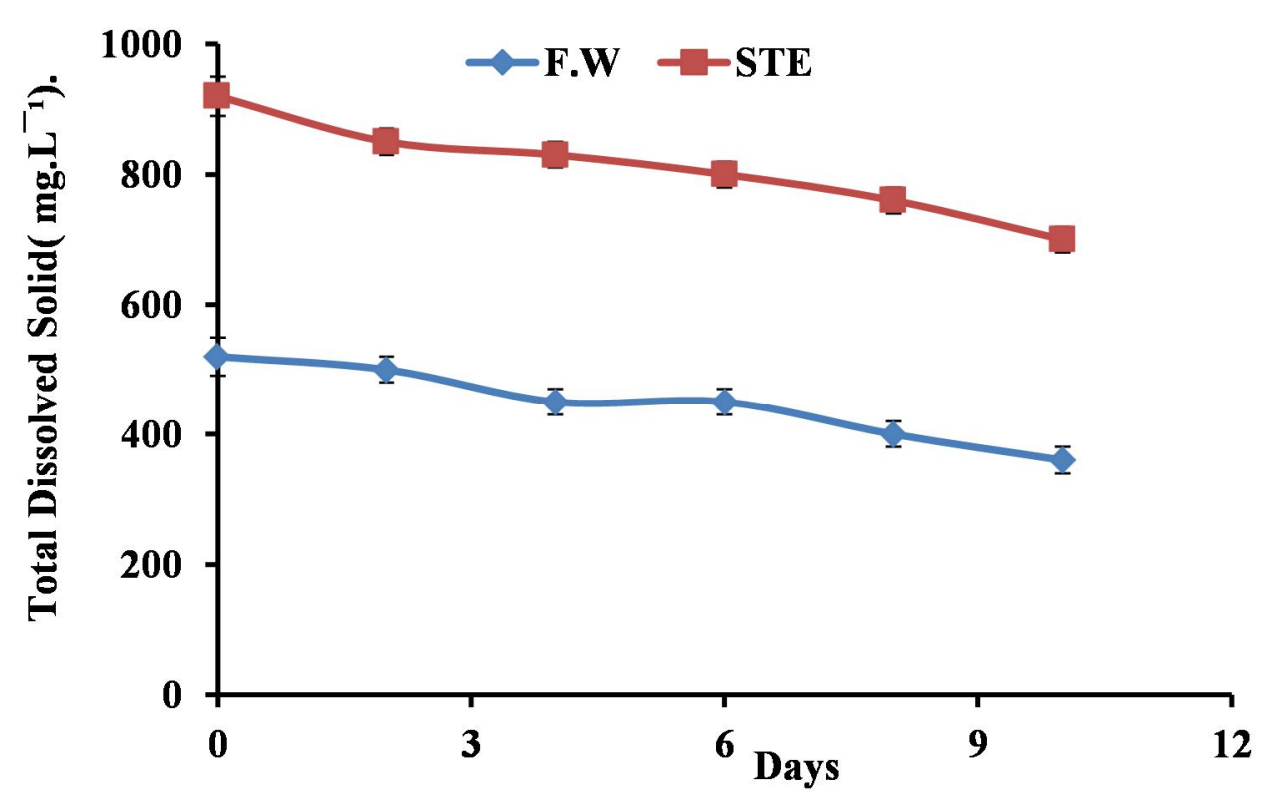

Figure 9. Variation of TDS vs. time (days) using STE as compared to FW during the closed cycle (10 days operation). Both treatments contained the same quantity of macro and micronutrients.

\section{Variation of EC and TDS with time during closed cycle}

Figures 8 and 9 summarize the variation of EC and TDS versus time during one closed cycle (10 days). On the 1st day from the beginning of the Epuvalisation cycle, two doses of the same quantity of fertilizers were added to both treatments (STE and FW). The results demonstrate that there is a gradual decrease in EC and TDS during the monitoring period. This reduction can be attributed to 
the plant uptake of the various nutrients.

\section{CONCLUSION}

This research demonstrated that the application of Epuvalisation technology using rosemary plants ( $R$. officinalis) achieved multi-objective goals of maintaining sustainable environment with highly economic technology providing additional social benefits. This work demonstrates that the Epuvalisation system is simple, flexible and easily managed with a low cost. The study revealed that rosemary plants ( $R$. officinalis) have a good efficiency in terms of STE polishing with significant reduction of TDS, COD and BOD. The biological growth parameters of the plant and the chemical analysis of roots, stems and leaves showed no significant difference between irrigation with STE as compared FW. Hence, it can be concluded that rosemary plants ( $R$. officinalis) can be used effectively in Epuvalisation technology with the added value of cropping a highly beneficial plant which is used as pest control in gardens and its leaves are used as food flavoring.

\section{RECOMMENDATIONS}

This project showed no negative impact on the operation of the wastewater treatment plant or on the environment. In the contrary, it showed improvements on the quality of treated wastewater, thus it is highly recommended to incorporate this technique for better purification of the water generated from wastewater plant.

\section{REFERENCES}

Al-Jayyousi OR, 2013. Grey water reuse: Towards sustainable water management. Desalination, 156: 18I-I92.

Bozdogan E, 2015. Re-use of treated wastewater for irrigation of Rosmarinus officinalis L. J Hortic Sci Biotechnol, 90(6): 711-714.

Burlando B, Verotta L, Cornara L, Bottini-Massa E, 2010. Herbal Principles in Cosmetics Properties and Mechanisms of Action. Boca Raton, Florida: CRC Press. p. 303.

Dunn OJ, 1958. Estimation of the means for dependent variables. Ann Math Stat, 29(4): 1095-1111.

Eaton AD, 2005, Standard Methods for Examination of Water and Wastewater Analysis, xx edition, American Public Health Association (APHA), Washington D.C.

Fayaz A, Hossein HD, 2011. Investigation of irrigation influence with domestic wastewater on quantity and quality features in different mint's species. Adv Appl Sci Res, 2(5): 1557-1560.

Food Agency Organization FAO, 2007. Water Quality for Irrigation, Handbook-eng-33.

Kamyab H, Md Din MF, Keyvanfar A, Abd Majid MZ, Talaiekhozani A, Shafaghat $A$, Lee CT, Shiun LJ, Ismail HH, 2015. Efficiency of microalgae Chlamydomonas on the removal of pollutants from Palm Oil Mill Effluent (POME). Energy Procedia, 75: 2400-2408.
Kamyab H, Md Din MF, Hosseini SE, Ghoshal SK, Ashokkumar V, Keyvanfar A, Shafaghat A, Lee CT, Bavafa AA, Abd Majid MZ, 2016. Optimum lipid production using agro-industrial wastewater treated microalgae as biofuel substrate. Clean Technol Policy, 18: 25132523.

Khalaf S, Khalaf S, Al-Rimawi F, Khamis M, Nir S, Bufo SA, Scrano L, Mecca G, Karaman R, 2015. Efficiency of membrane technology activated charcoal and a Clay Micelle complex for the removal of Ibuprofen and Mefenamic acid. Case Stud J, 4(5): 38-73

Khalid KA, 2006. Influence of water stress on growth, essential oil and chemical composition of herb (Ocimum basilicum L.). Int Agrophys, 20: 289-296.

Khamis M, Karaman R, Qurie M, Abbadi J, Nusseibeh S, Manassra A, Nir S, 2012. Performance of Micelle-Clay Filters for Removing Pollutants and Bacteria from Tertiary Treated Wastewater. J. Environ. Sci. Eng. A I, 160-168.

Khan M, Shaukati S, Khan MA, 2008. Economic Benefits from Irrigation of Maize with Treated Effluent of Waste Stabilization Ponds. Pak J Bot, 40(3): 1091-1098.

Murphy J, Riley JR, 1977. A modified single solution method for the determination of phosphate in natural waters. Anal Chem, 27: 31-36.

$\mathrm{Ng} \mathrm{HY}$, Lee LY, Ong SL, Tao G, Viawanath B, Kekre K, Lay W, Seah H, 2008. Treatment of $R O$ brine-towards sustainable water reclamation practice. Wat Sci Technol, 58(4):931-936.

Palestinian Water Authority PWA, 2003. Guidelines for the reuse of treated wastewater, Palestinian Standard PS 742-2003.

Qurie M, Abbadi J, Scrano L, Mecca G, Bufo SA, Khamis M, Karaman $R$, 2013. Inland treatment of the brine generated from reverse osmosis advanced membrane wastewater treatment plant using Epuvalisation system. Int J Mol Sci, 14(7): 13808-13825.

Ryan J, Garabet S, Harmsen K, Rashid A, 1996. A soil and plant analysis manual adapted for the West Asia-North Africa region. ICARDA Tech. Bulletin.

Sbeih YM, 1996. Recycling of treated wastewater in Palestine: Urgency, obstacles and experience to date. Desalination, 106: 165178.

Trivedy RK, 2007. Low cost and energy saving technologies for water and wastewater treatment. J Ind Poll Cont, 23: 403-411.

Vo PT, Ngo HH, Guo W, Zhou JL, Nguyen PD, Listowski A, Wang XC, 2014, A mini-review on the impacts of climate change on wastewater reclamation and reuse. Sci Total Environ, 494: 9-17.

World Health Organization WHO, 2008. Guidelines for Drinking Water Quality.

Xanthoulis D, Dumont $P$, Wauthelet $M, 2003$. Epuvalisation: a developing technique. Experiences, results in different countries. Second International Symposium on ecological sanitation 7th - 11th April 2003. Lubeck, Germany.

Citation: Qurie M, Daghra S, Khamis M, Kanan A, Barghouthi Z, Alimari A, Nussiebah S, Karaman R, 2019. Rosemary (Rosmarinus officinalis) plants irrigation with secondary treated effluents using epuvalisation technology. Net J Agric Sci, 7(2): 69-77. 